\title{
STRATEGI DINAS PERHUBUNGAN MENERAPKAN REGULASI ANGKUTAN ONLINE DALAM MENAMBAH PENDAPATAN ASLI DAERAH (PAD) DI KOTA PALANGKA RAYA
}

\author{
The Strategy Of The Transportation Service To Apply Online Transport Regulation \\ In Adding Indigenous Revenue (PAD) In The City Palangka Raya
}

\section{Rahmat Hidayat* \\ Diani}

Universitas

Muhammadiyah

Palangkaraya, Palangka Raya, Central Kalimantan, Indonesia

email:

rahmat.hidayat@umpalangkaraya.ac.id

\section{Kata Kunci:}

Regulasi

Angkutan Online

Pendapatan Asli Daerah

\section{Keywords:}

Regulation

Online Transport

Local Indigenous Revenue

\begin{abstract}
Abstrak
Angkutan Umum adalah angkutan dari suatu tempat ke tempat lain dalam wilayah Umum dengan mempergunakan mobil bus umum dan mobil penumpang umum yang terikat dalam trayek tetap teratur. Sedangkan angkutan online adalah salah satu penyelenggaraan lalu lintas dan angkutan jalan yang mengandalkan dan memanfaatkan perkembangan ilmu pengetahuan dan teknologi. Alat angkut yang menggunakan kendaraan pribadi yang dihubungkan dengan sebuah aplikasi. Tujuan dari penelitian ini untuk strategi dinas perhubungan menerapkan regulasi angkutan online dalam menambah pendapatan asli daerah (PAD) di kota palangkaraya. dan untuk mengetahui apa saja dampak positif dan negatif strategi dinas perhubungan menerapkan regulasi angkutan online dalam menambah pendapatan asli daerah (PAD) di Kota Palangkaraya.

Selama ini angkutan online tidak memiliki izin (ilegal) untuk beroperasi yang menjadi salah satu aspek yang memunculkan konflik berkepanjangan diantara angkutan online dan angkutan umum. Karena berdampak pada Pendapatan Asli Daerah karena banyak pengusaha-pengusaha angkutan umum mungkin telah berpindah ke angkutan online. PM No. I 8 Tahun 2018 tentang angkutan sewa khusus adalah regulasi yang dipakai saat ini. Penelitian menggunakan metode kualitatif yang menghasilkan data deskriptif mengenai kata-kata lisan maupun tertulis. Dan hasil penelitian yang dilakukan penulis menemukan bahwa Dinas Perhubungan belum menerapkan regulasi angkutan online yang baru karena belum mempunyai izin operasi Pemerintah Kota Palangka Raya tidak Mendapatkan Retribusi dari angkutan online dengan demikian tidak ada penambahan Pendapatan Asli Daerah di Kota Palangka Raya.
\end{abstract}

\begin{abstract}
Public transport is transport from one place to another within the general region by using public bus cars and public passenger cars that are bound to the route remains organized. While online transport is one of the traffic and road transport events that rely on and utilize the development of science and technology. A transport device that uses a private vehicle associated with an application. The objectives of this research for the Transportation Service strategy apply the regulation of online transport in increasing the regional original income (PAD) in the city of Palangkaraya. And to find out what are the positive and negative impacts of the Transportation Service strategy to apply the regulation of online transport in increasing the regional original revenue (PAD) in the city of Palangkaraya.

During this time the online transport has no permission (illegal) to operate which is one aspect that raises the prolonged conflict between online and public transport. Because of the impact on regional indigenous revenue since many entrepreneurs-public transport entrepreneurs may have moved to online transport. PM No. I I 8 the year 2018 about special rental transport is the current regulation. The research uses qualitative methods that generate descriptive data on spoken and written words. And the results of the authors of research found that the Department of Transportation has not implemented new online transport regulations because it does not have the operation license of municipal government Palangka Raya does not get retribution of the online transport with There is no additional regional income in the city of Palangka Raya.
\end{abstract}

Accepted

January 2019

Published

April 2019 yaitu banyaknya sistem layanan angkutan umum yang ditawarkan di internet salah satunya layanan jasa angkutan yang berbasis online. Mungkin perkembangan sistem layanan angkutan online bukan hal yang baru lagi
Perkembangan teknologi saat ini telah berkembang sangat pesat. Salah satu perkembangan teknologi saat ini

\section{PENDAHULUAN}


di Indonesia saat ini. Berkembangnya teknologi informasi adalah suatu keniscayaan bagi segala bidang usaha. Berbagai inovasi diciptakan untuk memberikan manfaat positif bagi kehidupan manusia serta memberikan banyak kemudahan dalam melakukan aktifitas manusia. Tidak ada satupun bidang usaha yang tidak tersentuh dan memanfaatkan perkembangan teknologi termasuk dalam perkembangan sistem angkutan umum itu sendiri.

Angkutan online muncul ditengah kondisi sistem angkutan umum di Indonesia belum tertata dengan baik. Beberapa perusahaan besar berlombalomba untuk membentuk angkutan umum menjadi angkutan berbasis online. Angkutan online menjadi jasa yang efisien untuk digunakan, yaitu dengan pemesanan melalui aplikasi ataupun melalui website secara online melalui smartphone. Jasa angkutan umum berbasis online yang telah hadir di Kota Palangkaraya yaitu Neojek Palangkaraya, ELJEK Palangkaraya, Mesanih, Grab dan Go-jek.

Pelayanan angkutan online memberikan layanan-layanan yang tidak ada pada jasa pelayanan angkutan umum konvensional. Pelayanan angkutan online memberi cukup kemudahan dalam pemesanan sebuah angkutan dengan mengakses aplikasi angkutan online untuk mendapatkan pengemudi dengan mudah. Hadirnya angkutan online di Kota Palangkaraya menjadi salah satu hal positif bagi masyarakat Kota Palangkaraya yang ingin berpindah lokasi ke suatu tempat ke tempat lainnya ataupun ingin memesan makanan atau barang dan sebagainya dengan mudah dan cepat.

Dalam Undang-undang RI No. 22 Tahun 2009 Pasal I 38 ayat 3 tentang Lalu Lintas dan Angkutan Jalan dinyatakan bahwa angkutan umum orang dan/atau barang hanya dilakukan dengan kendaraan bermotor umum. kendaraan pribadi/plat hitam (sepeda motor, mobil penumpang, mobil barang) dengan aplikasi internet bukanlah termasuk angkutan umum sebagaimana yang diatur dalam Undang-undang RI No. 22 Tahun 2009 tentang lalu lintas dan angkutan jalan. Pelanggaran lain yang dilakukan oleh angkutan online antara lain adalah terhadap Pasal 139 ayat 4 penyedian jasa angkutan umum dilaksanakan oleh Badan Usaha Milik Negara (BUMN), Badan Usaha Milik Daerah (BUMD), dan/atau Badan Hukum lain sesuai dengan ketentuan peraturan perundang-undangan dan pada Pasal I 73 ayat I tentang angkutan jalan menyatakan perusahan angkutan umum yang menyelenggarakan angkutan dan/atau barang wajib memiliki izin penyelenggaraan angkutan. Sedangkan angkutan online di Kota Palangkaraya belum memiliki izin operasi angkutan.

Pemerintah daerah Kota Palangkaraya harus segera merumuskan regulasi yang tepat dan tidak memihak salah satu pihak, mengingat bahwa angkutan umum berbasis online maupun angkutan umum konvensional juga memiliki hak yang sama untuk menjalankan usahanya. Dalam menangani permasalahan angkutan umum akan dikembangkan sistem angkutan yang modern dan tarif yang terjangkau. Ciri khas angkutan online yang selalu menawarkan kemudahan dan kenyamanan bagi masyarakat menjadi alasan masyarakat berpindah dari angkutan umum konvensional ke angkutan berbasis online. Ini menjadikan permasalahan bagi driver angkutan umum konvensional mengeluh karena penurunan pendapatan perharinya semenjak beredarnya angkutan online. Dan juga implikasinya berdampak pada Pendapatan Asli Daerah karena banyak pengusaha-pengusaha angkutan umum mungkin telah berpindah ke angkutan online.

Salah satu yang dapat menambah Pendapatan Asli Daerah (PAD) yang didapat melalui angkutan umum yaitu izin operasi angkutan dan lain sebagainya pada angkutan umum. Sebagaimana diketahui bahwa angkutan umum konvensional melakukan uji kir, bayar pajak, izin trayek dan kontribusi lainnya kepada Pemerintah Daerah. Sedangkan angkutan online telah merambat luas dan sudah ada dimana-mana tidak ada kontribusinya 
ke Pemerintah Daerah karena belum ada izin dari Pemerintah Daerah.

Salah satu penelitian terdahulu terhadap potensi Pendapatan asli daerah angkutan umum adalah dalam penelitian Irma Mohammad (2016) berjudul Manajemen Retribusi Angkutan Umum Pada Dinas Perhubungan, Komunikasi, dan Informatika Kota Palu. Pada penelitiannya menjelaskan salah satu sumber penerimaan yang menjadi andalan daerah antara lain berasal dari sektor retribusi selain pajak. Penerimaan yang bersumber dari sektor retribusi mempunyai potensi yang cukup besar sehingga dibutuhkan upaya untuk dapat meningkatkan penerimaan. Penetapan besar target retribusi yang harus dicapai setiap tahun disusun berdasarkan jumlah angkutan umum yang telah memiliki izin operasi. Setiap angkutan umum dipungut retribusi berdasarkan kriteria jenis angkutannya.

Berdasarkan Peraturan Daerah (Perda) Kota Palangkaraya No. 4 tahun 20II Bab II Pasal 2 tentang Retribusi Izin Trayek. Disebutkan dengan nama retribusi izin trayek dipungut retribusi sebagai pembayaran atas pemberian izin trayek kepada orang pribadi atau badan untuk menyediakan pelayanan angkutan penumpang umum pada suatu atau beberapa trayek tertentu dalam wilayah Kota Palangkaraya. Jelas ada kaitannya dengan penambahan/peningkatan Pendapatan Asli Daerah (PAD).

\section{METODOLOGI}

Penelitian ini bertujuan untuk menganalisis dan merumuskan strategi Dinas Perhubungan Kota Palangkaraya menerapkan regulasi angkutan online dalam menambah Pendapatan Asli Daerah Kota Palangkaraya. Alasan peneliti menggunakan tipe dekriptif dengan pendekatan kualitatif pada penelitian ini karena peneliti berusaha untuk melihat dari situasi sosial yang terjadi di masyarakat sehingga memudahkan peneliti dalam menganalisis dan merumuskan strategi penerapan regulasi angkutan online dalam menambah Pendapatan Asli Daerah Kota Palangkaraya.

Lokasi penelitian dilakukan pada Dinas Perhubungan, mengingat Dinas Perhubungan merupakan instansi yang berwenang dalam melakukan fungsinya sebagai penyelenggaraan urusan Pemerintah dan pelayanan umum dibidang lalu lintas, angkutan, teknik prasarana dan parkir serta pembinaan dan pelaksanaan tugas di bidang lalu lintas, angkutan, teknik prasarana terminal dan parkir.

\section{HASIL DAN PEMBAHASAN}

Dari hasil yang ditemukan, Dalam UU Nomor 22 Tahun 2009 tentang lalu lintas dan angkutan jalan. Regulasi tersebut tidak ada menjelaskan mengenai angkutan online atau angkutan sewa khusus secara jelas tentang penyelenggaraan angkutan online ini hanya menjelaskan tentang angkutan dalam trayek dan tidak dalam trayek sedangkan, angkutan online adalah angkutan sewa khusus dengan mekanisme yang berbeda dengan angkutan lainnya yaitu dengan aplikasi. Karena, tidak ada mengatur secara jelas mengenai angkutan online ini Pemerintah mengeluarkan regulasi Peraturan Menteri Perhubungan atau PM No. II8 Tahun 2018 tentang penyelenggaraan angkutan sewa khusus untuk memperkuat. Walaupun sebelumnya sering menggontaganti regulasi untuk angkutan online ini.

Dalam aturan tersebut Dinas Perhubungan Kota Palangka Raya masih memakainya dan masih berlaku untuk angkutan umum yang konvensional atau yang dalam trayek. Sedangkan untuk angkutan online sementara ini menggunakan regulasi atau peraturan yang baru yaitu PM No. 118 tahun 2018 tentang penyelenggaraan angkutan sewa khusus yang sebelumnya menggunakan PM No.108 Tahun 2017. Namun, angkutan online yang lagi marak digunakan masyarakat masih belum punya izin di Kota Palangka Raya. Dalam Undang-undang No. 22 Tahun 2009 
tentang lalu lintas dan angkutan jalan sebenarnya tidak diatur untuk sepeda motor sebagai sarana angkutan umum.

Angkutan online memang sangat menjadi peluang kerja masyarakat untuk mengais rezeki. Tetapi, dengan keberadaan angkutan online ini mengancam keberadaan taksi kota atau angkutan kota/angkot, dengan kenyamanan yang ditawarkan pemilik angkutan online secara otomatis memudahkan masyarakat dalam mencari angkutan dalam kota. Masyarakat tidak lagi direpotkan mencari angkutan 39 sekarang karena angkutan online beroperasional selama 24 jam.

Dinas Perhubungan Kota Palangka Raya tidak bisa mengunakan UU No 22 Tahun 2009 tentang lalu lintas dan angkutan jalan karena tidak ada dijelaskan untuk aturan angkutan online. Untuk regulasi PM No. 108 tahun 2017 telah digugat dari pihak angkutan telah gugur dan berubah menjadi PM No. II8 Tahun 2018. Oleh karena itu, Dinas Perhubungan Kota Palangka Raya tidak bisa menerapkan angkutan sewa khusus atau angkutan online ini di Kota Palangka Raya. Karena masih menunggu SK Gubernur untuk penetapan wilayah, kuota unitnya untuk kota, daerah dan kabupaten lainnya dan juga menetapkan tarif atas dan tarif bawah. Jadi kami tinggal menunggu SK Gubernur baru Dinas Perhubungan bisa menjalankan izin-izinnya. Jika tanpa SK Gubernur Dinas Perhubungan tidak berani dan tidak ada dasar untuk menjalankan tugas. Di dalam PM No. II8 tahun 2018 itu ditulis harus ada SK dari Gubernur. Sedangkan masalah penambahan pendapatan asli daerah dari angkutan online ini Dinas Perhubungan belum ada dan strategi untuk angkutan sewa khusus atau angkutan online ini Dinas Perhubungan mungkin akan mengikuti dari SOP Kementerian.

Selama ini sebenarnya angkutan online juga tidak berani jika tidak ada SK Gubernur jadi angkutan online beroperasi melalui dengan aplikasinya langsung dari pusat. Oleh karena itu, Dinas Perhubungan Kota Palangka Raya tidak berani membatasi angkutan online ini karena belum adanya SK Gubernur atau dasar hukumnya. Dinas Perhubungan Kota Palangka Raya juga belum pernah menerapkan regulasi PM No.108 Tahun 2017 sebelumnya dan sekarang regulasi PM No 108 Tahun 2017 tersebut telah digugat atau diganti dan Gubernur sekarang sudah mulai membuat SK dengan memakai regulasi baru yaitu PM No. II8 Tahun 2018 tentang penyelenggaraan angkutan sewa khusus ini.

Didalam PM No. II8 Tahun 2018 dijelaskan bahwa tetap mengutamakan keselamatan dengan menerapkan standar pelayanan minimal (SPM), penetapan batas tarif, serta mengatur suspensi bagi mitra pengemudi. Ada juga beberapa batasan untuk angkutan online ini di dalam regulasi baru tersebut agar tidak terjadi masalah semakin besar dengan menghimbau angkutan online untuk tidak mangkal atau parkir di tempattempat umum tidak boleh menarik penumpang dari bandara, terminal dan menarik penumpang di pinggir jalan karena itu, sudah ada angkutannya tersendiri. Jadi, mereka harus menarik penumpangnya melalui aplikasi.

Dinas Perhubungan Kota Palangka Raya hanya bisa mengatur angkutan online dengan mengingatkan atau menegur angkutan online jika melakukan pelanggaran atau hal-hal lain yang dilarang melalui surat. Dinas Perhubungan Kota Palangka Raya juga menyarankan agar angkutan online harus melakukan atau wajib uji kir demi keselamatan penumpang dan driver. Jadi, jangan sampai perusahaan meraup keuntungan tetapi tidak memikir keselamatan penumpang dan driver. Dinas Perhubungan Kota Palangka Raya akan menjaga keuntungan angkutan-angkutan untuk menjamin keamanan penumpang. Angkutan online telah terlanjur beroperasi di Kota Palangka Raya hal ini tidak dapat dicegah karena semua proses transaksi dilakukan secara online dan angkutan online akhirnya tetap beropersi karena kebutuhan masyarakat.

Dengan persoalan itu Dinas Pehubungan Kota Palangka Raya mulai menyarankan agar angkutanangkutan online untuk registrasi ulang kembali supaya bisa membedakan 
antara travel antar-jemput dengan angkutan sewa khusus/angkutan online. Jika angkutan-angkutan ini telah registrasi ulang terlebih dahulu di Samsat maka akan mengganti plat belakangnya menjadi AO (angkutan online) dan angkutan penumpang dulu AP (angkutan penumpang) didalam PM No.II8 Tahun 2018 itupun prosedur tetap berjalan. Dengan begitu jika Dinas Pehubungan melakukan razia tidak bingung untuk membedakannya antara angkutan konvensional dengan angkutan online dan Dinas Perhubungan akan tahu apa saja yang akan diperiksa.

Dalam aturan PM No.II8 Tahun 2018 mewajibkan semua perusahaan angkutan online memiliki izin penyelenggaraan dari pemerintah. Dalam pengurusan izin tersebut juga dikenakan biaya sebagai Penerimaan Negara Bukan Pajak (PNBP) dan retribusi daerah. Terbitnya peraturan ini mendapat sambutan positif dari pelaku usaha angkutan online dinilai sudah lebih mengakomodir seluruh pemangku kepentingan seperti perusahaan angkutan online, driver serta penumpangnya dibandingkan dengan peraturan sebelumnya dan juga regulasi ini berdampak positif bagi masyarakat karena dalam regulasi/aturan didalamnya memuat pengawasan, perlindungan masyarakat agar aman dan terjamin keselamatan dalam mengunakan angkutan online. Sedangkan dampak negatif dari menerapkan regulasi angkutan online ini adalah masalah tarif angkutan dimana pemerintah telah menentukan besarannya. Jika penentuan tarif diserahkan pada perusahaan angkutan online tentu berdampak negatif bagi perusahaan konvensional karena akan menguntungkan bagi perusahaan angkutan online sedangkan untuk angkutan konversional merasa dirugikan.

Mengenai angkutan online yang menggunakan sepeda motor dalam Undang-undang No. 22 Tahun 2009 tidak ada mengatakan sepeda motor adalah angkutan umum mengingat penyumbang angka kecelakaan terbesar adalah sepeda motor. Ada dampak negatif lainnya terlihat dari data jumlah armada angkutan umum dalam trayek pada tahun 2017-2018 yang mengalami penurunan diakibatkan karena adanya angkutan online dan juga disebabkan angkutan tidak layak operasi karena telah rusak terlihat dalam tabel dibawah ini:

Tabel I.I

Data Jumlah Armada Angkutan Dalam Trayek di Palangka Raya Tahun 2018

\begin{tabular}{|c|c|c|c|c|}
\hline \multirow{2}{*}{ No } & \multirow{2}{*}{ Jenis Angkutan } & \multicolumn{3}{|c|}{ Jumlah Armada } \\
\cline { 3 - 5 } & & Data Awal & Data 2017 & Data 2018 \\
\hline 1. & MPU (Angkot) & 430 & 367 & 187 \\
\hline 2. & Taksi Bandara & 32 & 32 & 32 \\
\hline & JUMLAH & $\mathbf{4 6 2}$ & $\mathbf{3 9 9}$ & $\mathbf{2 1 9}$ \\
\hline
\end{tabular}
Sumber: Data Olahan Dinas Perhubungan Kota Palangka Raya Tahun 2019

Dari tabel tersebut dapat dilihat bahwa angkutan kota menurun lebih 243 angkutan dari awal hadirnya angkutan sampai tahun 2018. Seperti dikatakan bahwa penurunan jumlah angkutan tersebut ada dua sebab karena kurang merawat angkutan yang menjadi angkutan tidak dapat beroperasi lagi dan para driver angkutan mungkin telah berpindah menjadi driver angkutan online.

Berdasarkan Undang-undang No. 33 Tahun 2004 Pasal I Pendapatan Asli Daerah yang selanjutnya disebut PAD, yaitu penerimaan yang diperoleh daerah dari sumber-sumber dalam wilayahnya sendiri yang dipungut berdasarkan Peraturan Daerah sesuai dengan peraturan perundang-undangan yang berlaku. Salah satunya dari retribusi daerah Retribusi daerah Berdasarkan Undangundang No. 28 tahun 2009 retribusi atau yang disebut dengan retribusi daerah adalah pungutan daerah sebagai pembayaran atas jasa atau pemberian izin tertentu yang khusus disediakan atau diberikan oleh Pemerintah Daerah kepada orang pribadi dan badan. Jasa yang dimaksud adalah kegiatan Pemerintah daerah berupa usaha dan pelayanan yang menyediakan barang, fasilitas atau kemanfaatan lainnya yang dapat dinikmati oleh orang pribadi atau badan.

Tetapi, Dinas Perhubungan Kota Palangka Raya telah kelewatan memanfaatkan Pendapatan Asli Daerah dari perusahan angkutan online tersebut di Kota Palangka 
Raya. Padahal jika dilaksanakan sangat dimungkinkan akan menambah Pendapatan Asli Daerah. Dari angkutan kota pun tidak begitu menambah pendapatan asli daerah atau bisa dikatakan sangat menurun Pendapatan Asli Daerahnya dari angkutan kota yaitu \pm Rp.2000.000,Perbulannya dari 187 angkutan kota. Jika dilihat diawal jumlah angkutan kota sebanyak 430 unit maka yang didapatkan bisa mencapai \pm Rp.4.500.000,- perbulannya.

Setiap angkutan umum dipungut retribusi berdasarkan kriteria jenis angkutannya yaitu angkutan kota membayar retribusi Rp. 500,- setiap kali lewat, AKDP (angkutan kota dalam provinsi) sebesar Rp. 5000,- sekali jalan dan AKAP (angkutan kota antar provinsi) sebesar Rp. 15.000 sekali jalan, sedangkan penumpang antar jemput atau sewa khusus sekali berangkat dipungut retribusi sebesar Rp. 5000,- dan direkapitulasi terhadap hasil pungutan retribusi terminal setiap I (satu) minggu sekali dan I (satu) bulan sekali. Apabila angkutan online telah dilakukan izin operasi angkutan maka bisa saja retribusinya makin bertambah karena, angkutan online tidak sedikit jumlahnya melainkan \pm 1000 jumlahnya ini termasuk mobil dan motor. Jika dihitung jumlah angkutan online sekitar 1000 angkutan maka pendapatan asli daerahnya sekitar \pm Rp 10.800.000,perbulannya. Tetapi, sayangnya tidak ada data yang lebih akurat berapa jumlah angkutan online yang sebenarnya karena Dinas Perhubungan Kota Palangka Raya pun tidak ada memiliki data tersebut. Adapun jumlah nilai retribusi jasa usaha dan retribusi perizinan dalam di tahun 2017, sebagai berikut:

Tabel I.2

Pendapatan Per Jenis Retribusi Pada APBD 2017

\begin{tabular}{|c|c|c|}
\hline JENIS RETRIBUSI & RINCIAN & NILAI \\
\hline $\begin{array}{c}\text { Retribusi Jasa } \\
\text { Usaha }\end{array}$ & $\begin{array}{c}\text { Retribusi Terminal - Fasilitas } \\
\text { Lainnya di Lingkungan Terminal }\end{array}$ & 0 \\
\hline & $\begin{array}{c}\text { Retribusi Terminal Tempat } \\
\text { Parkir untuk Kendaraan } \\
\text { Penumpang dan Bis Umum }\end{array}$ & 25.000 .000 \\
\hline $\begin{array}{c}\text { Retribusi Perizinan } \\
\text { Tertentu }\end{array}$ & $\begin{array}{c}\text { Retribusi Pemberian Izin Trayek } \\
\text { kepada Badan }\end{array}$ & 8.700 .000 \\
\hline \multicolumn{2}{|c|}{$\begin{array}{c}\text { Retribusi Pemberian Izin Trayek } \\
\text { kepada Orang Pribadi }\end{array}$} & 90.000 .000 \\
\hline Sumber : Data diolah bersumber dari daerah yang dikirimkan melalui \\
SIKD per tanggal 20 Februari 2018
\end{tabular}

\section{KESIMPULAN}

Strategi Dinas Perhubungan menerapkan regulasi angkutan online dalam menambah pendapatan asli daerah sampai saat ini belum dilaksanakan. Penyusunan program kerja dalam penyelenggarakan angkutan online belum dibuat dikarenakan SK Gubernur belum ada. Dengan begitu akibatnya untuk menambah pendapatan asli daerah juga belum didapatkan. Padahal Dinas Perhubungan tetap bisa menerapkan regulasi tersebut walaupun belum mendapatkan SK Gubernur karena bisa batal dari hukum jika SK Gubernur itu berbenturan dengan Peraturan Menteri dan juga Peraturan menteri lebih tinggi daripada SK Gubernur.

Dengan hadirnya angkutan online yang telah menyebar dimana-mana termasuk di Kota Palangka Raya sebagaimana yang telah dicantumkan di UU No. 22 Tahun 2009, tidak ada disebutkan tentang angkutan online sehingga pada kenyataannya pemerintah kecolongan terhadap adanya potensi pendapatan asli daerah di perusahaan angkutan online tersebut. Kehadiran angkutan online memberikan yang kurang baik terhadap angkutan kota, hadirnya angkutan online di Kota Palangka Raya menjadi semakin menurun jumlah armada angkutan kota. Dan Dinas Perhubungan berencana ingin mengganti plat angkutan online di belakang platnya menjadi AO (angkutan online). Seperti yang diketahui di belakang plat angkutan travel bertanda AP (angkutan penumpang).

\section{REFERENSI}

Ardilla, Riska. 2017. Peranan Retribusi Angkutan Kota Antar Provinsi Dalam Menggali Pendapatan Asli Daerah (PAD) Di Kota Bandar Lampung. Jurnal Pendidikan Ilmu Pengetahuan Sosial.

Debby Agatha, Herbasuki Nurcahyanto, dan Mariyam Musawa. 2012. Strategi Pengelolaan Angkutan Umum Jalan Raya di Kota Semarang. Jurnal Administrasi Publik. Volume I, No I.

Dirgantoro, Crown. 200I. Manajemen Stratejik Konsep, Kasus, dan Implementasi. Jakarta: PT Grasindo. 
Frans, John H, Jusuf J S Pah dan Maria G A Ikun. 2017. "Perpindahan Moda Angkutan Umum Ke Angkutan Pribadi di Kota Kupang". No. 2: 151.

Habeis, Musa dan Mukhamad Najib. 2008. Manajemen Strategik dalam Pengembangan Daya Saing Organisasi. Jakarta: Elex Media Komputindo

Hery. 2018. Manajemen Strategis. Jakarta: Grasindo.

Iriantara, Yosal. 2004. Manajemen Strategis Public Relations. Jakarta:Ghalia Indonesia.

Juhaini. 2018. Pengaruh Kehadiran Angkutan Online (Grab) Terhadap Sosial Ekonomi Supir Angkutan Umum (PT. Rahayu Medan Ceria Trayek 120). Jurnal Repositori Institut USU.

Mohammad, Irma. 2016. Manajemen Retribusi Umum Pada Dinas Perhubungan, Komunikasi Dan Informatika Kota Palu. Jurnal Katalogis. Volume 4, No 1.

Pranadita, Nugraha. 2018. Perumusan Strategi Perusahaan Interaksi Hukum Dengan Manajemen Strategis dalam Industri Pertanahan Indonesia. Yogyakarta: CV Budi Utama.

Sedjati, Retina Sri. 2015. Manajemen Strategis. Yogyakarta: CV Budi Utama.

Siagian, Sondang P. 2012. Manajemen Strategik. Jakarta: PT Bumu Aksara.

Supratikno, Hendrawan, dkk. 2003. Advanced Strategic Manajement. Jakarta: Gramedia Pustaka Utama.

Wahyusetyawati, Endang. 2017. Dilema Pengaturan Transportasi Online. Jurnal Rechtsvinding. I-3.

Wulandari, Phaureula Artha dan Emy Iryanie. 2018. Pajak Daerah dalam Pendapatan Asli Daerah. Yogyakarta: Deepublish.

Yunus, Eddy. 2016. Manajemen Strategis. Yogyakarta: CV Andi Offset.

\section{Perundang-Undangan}

Peraturan Daerah (Perda) Kota Palangkaraya Nomor 4 tahun 20II Tentang Retribusi Izin Trayek.

Peraturan Menteri Perhubungan No. PM 108 tahun 2017 tentang Penyelenggaraan Angkutan Orang dengan Kendaraan Bermotor Umum Tidak dalam Trayek.

Peraturan Menteri Perhubungan No. PM 118 Tahun 2018 tentang Penyelenggaraan Angkutan Sewa Khusus.

Undang-undang Republik Indonesia Nomor 22 Tahun 2009 Tentang Lalu Lintas dan Angkutan Jalan 